\title{
AMAZON ENDANGERED: INVESTIGATING CHICO MENDES'S \\ CASE IN ONLINE NEWSPAPERS
}

\section{AMAZÔNIA EM PERIGO: O CASO CHICO MENDES EM JORNAIS \\ ONLINE}

\author{
Martha Julia Martins (UFRR) \\ marthajumartins@gmail.com \\ Viviane Heberle (UFSC) \\ viviane.heberle@ufsc.br
}

\begin{abstract}
Chico Mendes was a Brazilian rubber tapper who fought against the destruction of the Amazon region and consequently was murdered by cattle ranchers in 1988. His death aroused great interest in national and international media, which reported his fight against landowners, releasing Chico Mendes's case worldwide. This work discusses six online articles published in the years of 1988 and 2008, by BBC, Folha de São Paulo, and The New York Times based on Critical Discourse Analysis (FAIRCLOUGH, 1995, 2006) and Systemic Functional Linguistics (HALLIDAY; MATTHIENSEN, 2004) assumptions. Results have shown that the lexicogrammatical choices portray Chico Mendes both as a leader and a martyr.
\end{abstract}

KEYWORDS: Chico Mendes's case; media; leader; Critical Discourse Analysis; Systemic Functional Linguistics.

RESUMO: Chico Mendes foi um seringueiro brasileiro que lutou contra a destruição da Amazônia e como consequência foi assassinado em 1988, por pecuaristas. Sua morte deu início a uma explosão de notícias nos meios de comunicação relatando sua luta contra donos de terra e lançando o caso Chico Mendes para o mundo todo. Este trabalho discute seis artigos publicados online nos anos de 1988 e 2008, pela BBC, Folha de São Paulo e The New York Times com base em pressupostos da Análise Crítica do Discurso (FAIRCLOUGH, 1995, 2006), Linguística Sistêmico-Funcional (HALLIDAY; MATTHIENSEN, 2004). Os resultados indicam que as escolhas lexicogramaticais retratam Chico Mendes como líder e mártir.

PALAVRAS-CHAVE: caso Chico Mendes, mídia, líder, Análise Crítica do Discurso; Linguística Sistêmica-Funcional. 


\section{Initial remarks}

Livestock farming in North Brazil is motivated by the low prices of lands, high profitability, fast return of investments and good weather conditions to ease the process, according to Arima et al. (2005). Similarly, the lack of control of the area by the Brazilian government makes the region attractive enough to grow soy and raise cattle recklessly. In spite of the embargos imposed for environmental violations, several landowners keep raising cattle and cutting down trees illegally in the region, violating environmental policies. As stated by Arima et al., (2005), "governmental intervention would be necessary to reconcile livestock farming with preservation [...] the risk of losing the biodiversity is increasing due to years of deforestation" (ARIMA et al., 2005, p. 53).

Livestock farming, together with agribusiness, remain key industries in Brazil, which leads to several other problems, such as deforestation, massive gas emissions and the reduction of natural resources available in the forest. Chico Mendes's fight comes within this context: as a rubber tapper who fought against deforestation and, as such, became an obstacle to landowners, even though he was constantly acknowledged by his ecological activism overseas. A year before his death, he won the Global 500 Award, a major award for environmentalists. He was born, raised and killed in the city of Xapuri, in the northern state of Acre, and his death made headlines around the world, which contributed to reinforce deforestation-control measures. After Chico Mendes was murdered, the Brazilian government suffered pressure from international organizations concerned with Brazil's ability to effectively manage the forest resources. This almost led to an international crisis, which Brazilian authorities converted into Eco 92, the International Summit on environmental issues that took place in Rio de Janeiro in 1992 (ALLEGRETTI, 2002; VENTURA, 2003).

More recently, Brazil has hosted Rio +20 to renew its commitment with sustainable development and to address more pressing challenges. Chico Mendes's death had a huge impact on the Amazon conservation movement, leading to a new kind of environmental activism in the area.

\section{Presenting the data}

This article consists of a qualitative analysis of the media discourse regarding the representation of the Brazilian rubber tapper, Chico Mendes, in six articles by BBC, Folha de São Paulo, and The New York Times from the years of 1988 - the year of his death - and 
2008, twenty years after his death. This analysis, based on Souza (2012) is an attempt at understanding Chico Mendes's case through the media lenses in order to reveal how he was portrayed by the press (both as a social actor and as an ecological activist). More specifically, the six articles were retrieved from the online newspapers The New York Times, BBC, and Folha de São Paulo. All the articles were collected in 2009, except the one taken from the BBC website, which was retrieved in May, 2011.

The articles from the BBC website in May 2011 were gathered from the section called News, which provides information from all over the world. They are the following: The life and legacy of Chico Mendes published on December $22^{\text {nd }}, 2008$, and Brazil remembers slain activist published on December $23^{\text {rd }}$. The articles from Folha de São Paulo are the following: Comissão anistia Chico Mendes com $R \$ 337$ mil; viúva receberá $R \$ 3.000$ mensais published on December $10^{\text {th }}, 2008$, and Chico Mendes é "Che Guevara da era ambiental" diz “Guardian" published on December $22^{\text {nd }}, 2008$. Lastly, the articles from The New York Times are the following: Brazilian who fought to protect the Amazon is killed published on December $24^{\text {th }}, 1988$, and Brazil burns the future published on December $28^{\text {th }}, 1988$.

In this study, the data is analyzed through a discursive approach based on Critical Discourse Analysis (henceforth CDA), aligned with Systemic Functional Linguistics (henceforth SFL). We attempt to demonstrate how language is used to construct Chico Mendes's identity and to understand the exploitation of the Amazon rainforest, the murders of local workers that go unpunished in the Amazon region, and the deficiency of rigorous monitoring of the forest by Brazilian authorities.

Even though there has been an increase in ecological awareness and strengthening of environmental protection laws (at present being unfortunately backlashed under president Bolsonaro's government, as it was broadcast by the Brazilian media), Chico Mendes is still a strong name that comes to memory when the Amazon rainforest is at issue despite recent attempts of harming his reputation (MARTINS, 2019) more than thirty years after his death. Ironically, it only proves that there is still a lot to address in terms of environmental matters in Brazil.

\section{Establishing our view of language}

\section{Discourse in a neoliberal society}

The gist of Fairclough's thought is based on the idea that global neoliberalism is an 
ongoing reality affecting our lives culturally, politically and socially, regulated mainly through the flow of information and capital. This logic would not only redefine market relations through wealth accumulation, but also destroy important ecological systems at the cost of more vulnerable people, since global neoliberalism has little or no concern with social welfare. The role of language is pivotal in this respect because it works as a medium of communication and persuasiveness. As Fairclough (2006, p. 31) suggests, "a discourse is a particular way of representing some aspect or area of social life" and it is language analysts' responsibility to be in charge of unmasking what is behind media production, since it influences peoples' attitudes, beliefs, values and practices.

Even though CDA can contribute to the unveiling of discourse in several fields of social life, it has its own limitation, because CDA "itself cannot however tell us which texts are significant in terms of the constitutive effects of discourse on social life - that requires institutional and historical forms of analysis" (FAIRCLOUGH, 2006, p. 41). Thus, we see the relevance of looking at language in the news as a complex social phenomenon which integrates people, organizations, governments and cultures, widening worldwide interconnectedness. By conceiving language in this way, it becomes possible to understand how a local issue, such as Chico Mendes's case received so much attention in the international media.

Yet, information is a multifaceted concept, because it not only informs people, but it also tries to convince them with a certain side of the story in order to maintain the interests of hegemonic actors. According to Santos (2000), for instance, power and information in contemporary society belong to those who can control time, space, capital, and the means of communication. Similarly, for Bauman (1999), the process of globalization as a time and space compressor affects the decisions people make and the access people have to capital and flows of information. To transpose time and space is to have the real control of political and economic mechanisms; those who do not, are excluded from the decision-making process. Bauman (1999, p. 08) points out that "being local in a globalized world is a sign of social deprivation and degradation". Therefore, (im)mobility determines levels of power in our society, thus "whoever is free to runaway of locality is free to escape from the consequences" (BAUMAN, 1999, p. 16).

In this sense, once Chico Mendes's cause became a collective struggle internationally acknowledged by important players such as the UN, he became an important player himself, which explains why many landowners wanted him dead, eliminated out of the decisionmaking context in the Amazon region. He was considered an impediment to progress, 
especially because the influence of neoliberal policies on the decisions of the development of agribusiness in the Amazon region favors landowners. Neoliberalism reconfigured the logic of private enterprises worldwide, thus affecting the way business were conducted in the region.

\section{Systemic Functional Linguistics (SFL): Context of situation and transitivity}

The close link between critical discourse analysis and SFL is emphasized by Martin (2000, p. 275), who explains that for Fairclough, "SFL is a congenial theory for CDA because it is multifunctional, well-adapted for text analysis and concerned with relating language to social context". Thus, for our linguistic analysis we draw on systemic functional linguistics, which "is oriented to the description of language as a resource for meaning; it is concerned with texts, rather than sentences; it focuses on the relations between texts and social contexts and it views language as a meaning-making system" (adapted from Halliday and Martin, 1993, p. 22-23).

From SFL in the present study, we focus on both the concept of the context of situation and on the system of transitivity. The "Context of Situation" refers to the features related to the activity or situation studied, which provide additional information about language. For Eggins (2004, p. 86) "context may function as the retrieval source to clear up indeterminacies of meaning". The context of situation describes three dimensions or registerial variables: field, tenor and mode. Halliday and Martin (1993, p. 32-33) explain:

$$
\begin{aligned}
& \text { FIELD - the social action: "what is actually taking place"... } \\
& \text { TENOR - the role structure: "who is taking part"... } \\
& \text { MODE - the symbolic organization: "what role language is playing" }
\end{aligned}
$$

For this reason, the variables of the context of situation provide relevant information to perceive what is going on in language use.

As for transitivity, which is related to the variable Field in the context of situation, it functions as a lexicogrammatical resource for representing the construction of what is going on, through the interaction among processes, participants and the circumstances involved in the construction of the linguistic reality (MARTIN; MATTHIESSEN; PAINTER, 1997; HALLIDAY; MATTHIESSEN, 2004). In other words, the transitivity system "shows how speakers encode in language their mental picture of reality and how they account for their experience of the world around them" (SIMPSON, 1993, p. 88). Processes, participants and attendant circumstances make up the configuration of transitivity structures, and each process 
is correlated with specific participants and optional circumstances. The three major types of processes are material (processes of doing and happening), relational (processes of being and having) and mental (processes of sensing). The other subsidiary processes are behavioral, verbal, and existential processes. In our analysis, we focus both on the context of situation and on the system of transitivity, as will be seen now.

\section{Results and discussion}

In this section, data will be tackled according to the concepts of Field, Tenor and Mode.

\section{Field: How Chico Mendes's case was represented in the newspaper articles}

In Hallidayian grammar, the field of a text tells which domain of the experience the text is about, since it is an element of the experiential metafunction of a text. Field is hence examined regarding its repercussion of Chico Mendes's case and his fight against landowners who explored the Amazon region, thus causing his death. Chico Mendes's case has received a lot of attention by the international press, especially after his murder.

In the present study, the articles analyzed describe Chico Mendes's story, portraying him as an activist who struggled against deforestation and was cowardly killed in his hometown in the state of Acre, showing lack of protection and neglect from Brazilian authorities. He was depicted as the person responsible for protesting in favor of improvement of the Amazon region without destroying natural resources, as the examples in the Transitivity analysis will show later.

\section{Tenor: The relations between journalists and their audiences}

The tenor of a text concerns the relationship between the producers of the text and the expected audience. The Tenor dimension indicates that the articles were written in relatively formal journalistic style centered on the figure of the journalist as the main expertise in Chico Mendes's life and case, especially if one considers the international newspapers BBC and The New York Times. Both seemed to be knowledgeable on Chico Mendes's case. The authors provided details about Brazilian rural workers in the same condition as Chico Mendes's, blaming the authorities for his death, and suggesting a sort of connivance with what was 
happening in the Amazon region. By contrast, Folha de São Paulo's articles did not contain substantial information on the case, and their main source of information was provided by the British newspaper The Guardian.

There seems to be an effort to depict Chico Mendes as emotionally closer to the audience, providing details of what happened back at the time and working on his heroic image. Chico Mendes is depicted as someone who cared enough to give his own life in favor of nature and environmental protection. Allegretti (2002) argues that some international newspapers knew sufficient information about his case, which could be noticed by the amount of detailed information on rubber tappers' fight. For instance, authorities had their correct names mentioned, the rubber tappers and families had their origins correctly specified, they were originally from the northeast region of Brazil trying to escape from the drought and they were looking for better living conditions. Moreover, the news reports showed deep knowledge by demonstrating Chico Mendes’s political affiliations during his political career.

\section{Mode: The language used to produce meaning}

Mode refers to the role of language and the kind of text produced. In this study, the channel of communication is the Internet, since all the articles were retrieved on the newspapers' websites. Online articles are easy to access, in a written-to-be-read format and are available to all kinds of audience, which in a way gives a global tone to a local event from Brazil. The news format does not seem to be completely monologic, since readers can exchange information with other readers, share the articles through their own social networks, and make comments on the comment sections, usually right below the article. This tool provided by most of the webpages nowadays increases the availability of an article, which seems to help disseminate the news.

\section{Transitivity analysis: Representation of Chico Mendes's case in the press}

The purpose of this section is to show how linguistic realizations were construed in respect to Chico Mendes's case. In terms of lexicogrammatical realizations, Chico Mendes is seen as the main participant in all the articles analyzed. Also, he was portrayed as someone concerned with local workers and the social-political context. Data revealed that the outcomes of Chico Mendes's fight can be felt even nowadays, and that his work towards the preservation of the Amazon is still recognized by Brazilian authorities. However, other 
participants were involved, with some being portrayed as victims and others as perpetrators. Chico Mendes, though, was explicitly portrayed in the articles as someone who devoted his life in favor of the Amazon forest. He is usually called by his name and is characterized by his social function in society (rubber tapper, social activist) or by the way the media decided to portray him (leader, the martyr). Sometimes portrayed as Subject (Actor or Affected), sometimes referred to as Goal or as part of Circumstances, Chico Mendes is always in the spotlight, as pointed out below:

- "He was shot dead outside his home" [Affected] (source: BBC)

- "Mr. Mendes, a trade unionist, defended the traditional rights of freelance rubber tappers (...)". [Actor] (source: The New York Times)

- "Brazil should give more recognition to people like Mendes (...)". [Goal] (source: $B B C)$

- “After Mr. Mendes's murder, the government began to set up extractive reserves (...)". [Circumstance] (source: BBC)

- "O jornal marca os 20 anos da morte do seringueiro, sindicalista e ativista ambiental brasileiro (...)" [Goal] (source: Folha de São Paulo)

- "A matéria principal, assinada por Tom Phillips, correspondente do jornal no Rio de Janeiro, destaca o legado de Chico Mendes (...)" [Goal] (source: Folha de São Paulo) Data reveals a predominance of $68 \%$ of Material processes (processes of doing and acting) in the articles analyzed. Brazilian Justice is portrayed acting in favor of Chico Mendes's case, while the perpetrators are portrayed negatively, as demonstrated below (Table 1 and Table 2). It can be considered strategic to focus on these two actors, because it somehow clears the Brazilian image toward international community, since it shows that Brazilian authorities are concerned with the environment (which, unfortunately, is not the case in 2019-2021, as previously mentioned). To state in a newspaper that Brazilian Justice was responsible for sending to jail two farmers has a huge impact on public opinion. It seems to convince readers that Brazil is committed with law enforcement and environmental regulation.

\begin{tabular}{|l|l|l|l|}
\hline A justiça & condenou & a 19 anos de prisão & os fazendeiros Darly Alves da Silva e Darcy Alves da Silva \\
\hline Actor & Material & Circumstance & Beneficiary \\
\hline
\end{tabular}

Table 1 - Folha de São Paulo - 2008

Source: the authors 


\begin{tabular}{|l|l|l|l|l|}
\hline Local landowners & had hired & gunmen & to kill & him \\
\hline Actor & Material & Goal & Material & Goal \\
\hline
\end{tabular}

Table 2 - The New York Times - 1988

Source: the authors

Other Material processes represent Chico Mendes as the leader of the rubber tappers and as the person responsible for fighting against deforestation. In the article Comissão anistia Chico Mendes com $R \$ 337$ mil: viúva receberá $R \$ 3.000$ mensais, the government is represented positively, providing for the widow and pardoning Chico Mendes for his activities once considered subversive, as shown below:

\begin{tabular}{|l|l|l|}
\hline $\begin{array}{l}\text { A anistia de Chico } \\
\text { Mendes }\end{array}$ & faz & $\begin{array}{l}\text { do Brasil um país mais importante, atento à questão dos direitos } \\
\text { humanos }\end{array}$ \\
\hline Actor & Material & Circumstance \\
\hline
\end{tabular}

Table 3 - Folha de São Paulo - 2008

Source: the authors

\begin{tabular}{|l|l|l|l|}
\hline $\begin{array}{l}\text { A comissão de anistia do } \\
\text { Ministério da Justiça }\end{array}$ & aprovou & hoje & $\begin{array}{l}\text { o pedido de anistia política do ex-líder } \\
\text { seringueiro Chico Mendes. }\end{array}$ \\
\hline Actor & Material & Circumstance & Goal \\
\hline
\end{tabular}

Table 4 - Folha de São Paulo - 2008

Source: the authors

Relational processes (14\% of occurrences) contribute specifically to construct the participants' identities. They give specific details from the region, the relationship among the participants, criticize Brazilian politics and show the aftermath for not protecting the forest. Relational processes construe the being by means of attribution and identification (HALLIDAY; MATTHIESSEN, 2004). Not only do the news reports praise Chico Mendes's actions, but also emphasize the fact that Brazil has many other environmentalists fighting the destruction of the Amazon region and dying because of it (cf. Table 5 and 6), as shown below:

\begin{tabular}{|l|l|l|}
\hline Mendes & era & um homem à frente do seu tempo \\
\hline Carrier & Relational: attributive & Attribute \\
\hline
\end{tabular}

Table 5 - Folha de São Paulo - 2008

Source: the authors 


\begin{tabular}{|l|l|l|}
\hline The country & has & "many Chico Mendes" \\
\hline Carrier & Relational: attributive & Attribute \\
\hline
\end{tabular}

Table 6 - BBC -2008

Source: the authors

Whereas in Material processes more attention is paid to the Brazilian Government, to the killers, and to Chico Mendes himself, in Relational processes, there is a predominance of other participants by showing their engagement with Chico Mendes's case, such as the World Bank, an institution that provides loans for developing countries, which contributes to reinforce the idea that international organizations are concerned with environmental issues in Brazil, as shown below:

The World Bank now places environmental conditions on its lending. Others who would help Brazil are also right to insist on respect for the common planetary heritage. (The New York Times - Brazil burns the future, 1988)

Both the World Bank and the Inter American Development Bank have lent large sums to Brazil to build a road to Rondônia and Acre that opened up the virgin forests of the western Amazon. (The New York Times - Brazil burns the future, 1988)

The third most predominant process found in the corpus is the Verbal one (13\% of occurrences) showing that participants were heard. A certain credibility is given to the news story because the quotes are from journalists and authorities involved in Chico Mendes's case, bringing a sense of fidelity to it. According to Fairclough (1995, p. 49), when the journalist's source grants any kind of information it means that "they are entitled to their experiences but not their opinions. The result is a predominantly establishment view of the world, manifested textually in, for instance, ways in which the reporting of speech is treated".

In relation to sources, the construction of a news story is not an individual and neutral process, but a collective and ideological one. Several professionals are involved in the news production, therefore, an article can be transformed in ways that correspond to the views of media producers and newspapers (FAIRCLOUGH, 1995, p. 48).

In other words, a news story is the result of several voices gathered to convince the audience of the veracity of a story. The lexicogrammatical choices refer to journalists, politicians, and others who helped to construe Chico Mendes's image. 


\begin{tabular}{|l|l|}
\hline Alfredo Sirkis, membro do Partido Verde e amigo de Chico Mendes, & afirma \\
\hline Sayer & Verbal \\
\hline
\end{tabular}

\begin{tabular}{|l|l|l|l|}
\hline que ainda não sabe & se a morte do ambientalista & foi & em vão \\
\hline Verbiage & & & \\
\hline
\end{tabular}

Table 7 - Folha de São Paulo - 2008

Source: the authors

\begin{tabular}{|c|c|c|}
\hline “Ele & falava & sobre assuntos a frente de seu tempo" \\
\hline Sayer & Verbal & Matter \\
\hline afirmou & [Marina] Silva & ao jornal. \\
\hline Verbal & Sayer & Receiver \\
\hline
\end{tabular}

Table 8 - Folha de São Paulo - 2008

Source: the authors

A Verbal process is also used to give voice to the Brazilian government itself. By stating that the Brazilian government announced a plan to reduce destruction in the Amazon, Brazil is actually making a statement to other global players interested in what happens inside its borders. In 1988, it was important for other countries to see that Brazil was well aligned with international policies to safeguard the environment.

\begin{tabular}{|l|l|l|}
\hline The Brazilian government & announced & a plan to reduce deforastation \\
\hline Sayer & Verbal & Verbiage \\
\hline
\end{tabular}

Source: the authors

The table below summarizes the processes and participants found in the articles.

\begin{tabular}{|l|l|}
\hline Process & Examples \\
\hline Material & $\begin{array}{l}\text { [Mr. Mendes] mobilized, to stop [the advance of loggers], protect, [Brazilian government] } \\
\text { sshrug off, defend, [Francisco Mendes Filho] had fought, [local landowners] had contracted, } \\
\text { [a viúva do ambientalista] receberá, [o ministro da Justiça, Tarso Genro] que prestigiou. }\end{array}$ \\
\hline Relational & $\begin{array}{l}\text { [two state policemen] were, [Mr.Mendes] had also become identified, [he] became known, } \\
\text { [the forest] was destroyed, [Ele] foi, [Sua anistia] é, [a material] é acompanhada. }\end{array}$ \\
\hline Verbal & $\begin{array}{l}\text { [he] said, [he] was told, said [Alfredo Sirkis, leader of the newly formed Brazilian Green } \\
\text { Party], [two large landowners] claim, [Mr. Mendes] said, [a material] cita, [as pessoas] } \\
\text { falam, diz [a coluna]. }\end{array}$ \\
\hline
\end{tabular}

\section{Table 10 - Occurrences of process types}

Source: the authors 
Other participants appeared in the articles showing how Brazilian authorities and other characters were involved. The title of one of the articles per se emphasizes the tittle of a previous one published by the Guardian which portrayed Chico Mendes as a martyr. The article focuses on the information that other 260 environmentalists live under the risk of assassination. Landowners (ranchers and loggers) are held responsible for the destruction of natural resources and for threatening people's lives, as the following passages show:

\begin{abstract}
A matéria cita um estudo da Comissão Pastoral da Terra, [...] que sugere que pelo menos 260 pessoas vivem sob o risco de assassinato por causa da luta contra um conjunto de fazendeiros, boiadeiros e madeireiras que operam na região amazônica. (Folha de São Paulo - Chico Mendes é "Che Guevara da era ambiental", diz “Guardian”, 2008).

In the 1970's, cattle ranchers had begun to move in from southern Brazil and were slashing and burning the forest. (BBC - The life and legacy of Chico Mendes, 2008)

His death comes at a time of increasing alarm over Brazil's development policy in the Amazon, which has set off a scramble for land by speculators and ranchers, who destroy vast stretches of rain forest every year. (The New York Times - Brazilian who fought to protect the Amazon is killed, 1988).
\end{abstract}

On the other hand, rubber tappers and their families are portrayed as those who try to avoid the destruction of the region. By sitting in front of the trees to prevent landowners from cutting down trees, locals and rubber tappers protested peacefully using a mechanism known as "embates".

At times, they [rubber tappers] and their wives and children would sit in front of bulldozers to stop landowners from illegally knocking down trees. (The New York Times - Brazilian who fought to protect the Amazon is killed, 1988).

The Transitivity analysis presented here gives a general idea of lexicogrammatical choices regarding Chico Mendes's case. It seems clear that Chico Mendes was treated by the international press as a leader who fought against deforestation, not against progress, as he was accused of in Brazil by loggers and landowners (ALLEGRETTI, 2002).

The relevance of a linguistic analysis is essential because as Fairclough (1995, p. 58) states: "the analysis is sensitive to absences as well as presences in texts - to representations, categories of participant, constructions of participant identity or participant relations which are not found in a text". Furthermore, it is important to understand "how relations are constructed in the media between audiences and those who dominate the economy, politics, and culture, is an important part of a general understanding of relations of power and domination in contemporary societies" (FAIRCLOUGH, 1995, p. 126). 
Far from being obsolete, Chico Mendes's fight is more relevant than ever, especially now that the ecosystem in Brazil is threatened by cattle ranching and soy cultivation with the connivance of important public figures. Recently, the European Union claimed that a trade deal with Mercosur would increase destruction in the Amazon rainforest and would jeopardize the future of the forest as well as global climate, which left the president of Brazil, Jair Bolsonaro, under international scrutiny for his environmental policies (DEUTSCHE WELLE, 2020).

\section{Final remarks}

This research aimed at analyzing Chico Mendes's case in four online newspapers: BBC, Folha de São Paulo and The New York Times. The relevance of studying Chico Mendes's case even today, more than thirty years after his death, relies on the fact that (i) Brazil is facing a serious reputational crisis in terms of environmental policies, thus (ii) bringing to light environmental destruction of the Amazon rainforest. These factors might help raise awareness to the fact that Brazil is becoming one of the greatest international pariahs of our times.

As pointed out, the fact that Chico Mendes is portrayed as a martyr, acting upon his surroundings, fighting for what he believed, demonstrates that news producers chose to depict Chico Mendes as someone who gave his life in favor of a bigger cause, since he had suffered five attempts against his life before being killed. It seems to be a consensus that Chico Mendes was a leader ahead of his time who proved that rubber extraction could be done sustainably.

Chico Mendes, as the main character is also depicted as a national hero in all processes linguistically analyzed - Material, Relational and Verbal ones. Other participants were differently represented. For instance, rubber tappers and other rural workers were shown as supporting and defending Chico Mendes's cause, while the killers were shown as the ones responsible for his death. Brazilian authorities were portrayed either as guilty of neglect or as incapable of law enforcement in the region.

Chico Mendes's case can be related to a broader discussion about global neoliberalism and the interests of speculators and farmers in the region whose focus is on exploitation, which fosters the dangerous degradation of the rainforest resources. The problem is that this destruction is about to reverberate on economic growth and the life on Earth. Disasters caused 
by the destruction of the Amazon rainforest can be responsible for hazards and deaths in the long run, not to mention irreversible risks of destroying what is already too scarce.

Chico Mendes's case is far from an ending, since there are still several Chico Mendes being killed nowadays in the same conditions as the real Chico was. It is not possible to specify the reasons why Chico Mendes gained so much notoriety, but there is no doubt that changes have occurred since his death, in the far-reaching North Brazil. Chico Mendes's fight causes turmoil even today, though his death was not in vain, since it has contributed to promote an alertness in the authorities, in the Brazilian press, and in Brazilian citizens. Nevertheless, there is still a lot to achieve in favor of the Amazon region.

\section{REFERENCES}

ALLEGRETTI, Mary. A construção social de Políticas Ambientais - Chico Mendes e o Movimento dos Seringueiros. 2002. Tese (Doutorado em Antropologia) - Centro de Desenvolvimento Sustentável, Universidade de Brasília, Brasília, 2002.

ARIMA, Eugênio; BARRETO, Paulo; BRITO, Marky. Pecuária na Amazônia: Tendências e Implicações para a conservação ambiental. Belém: Imazon, 2005.

BAUMAN, Zygmunt. Globalização: as consequências humanas. Rio de Janeiro: Editora Zahar, 1999.

DEUTSCHE WELLE. UE quer "compromisso claro" do Mercosul em relação ao meio ambiente. Deutsche Welle Brasil, Berlin and Bonn, 2020. Available at: https://www.dw.com/pt-br/ue-quer-compromisso-claro-do-mercosul-emrela\%C3\%A7\%C3\% A3o-ao-meio-ambiente/a-55008803. Accessed in: March 21, 2021.

EGGINS, Suzanne. An introduction to Systemic Functional Analysis. 2nd ed. London: Continuum, 2004.

FAIRCLOUGH, Norman. Language and Globalization: London and New York: Routledge, 2006.

FAIRCLOUGH, Norman. Media discourse. London: Arnold, 1995.

HALLIDAY, Michael; MARTIN, Jim R. Writing Science: Literacy and Discursive Power. Pittsburgh: University of Pittsburgh, 1993.

HALLIDAY, Michael; MATTHIESSEN, Christian. An introduction to functional grammar. London: Hodder Arnold, 2004. 
MARTIN, Jim R. Close reading: Functional linguistics as a tool for critical discourse analysis. In: UNSWORTH L. Researching language in schools and communities: Functional linguistic perspectives. London: Cassell, 2000. p. 275-302.

MARTIN, Jim R.; MATTHIESSEN, Christian; PAINTER, Clare. Working with functional grammar. London: Arnold, 1997.

MARTINS, Leonardo. Entenda a polêmica da fala do ministro do Meio Ambiente sobre Chico Mendes. Uol, São Paulo, 2019. Available at: https://noticias.uol.com.br/meioambiente/ultimas-noticias/redacao/2019/02/13/roda-viva-chico-mendes-ricardo-sallesirrelevante.htm?cmpid=copiaecola. Accessed in: May 08, 2021.

SANTOS, Milton. Por uma outra globalização: do pensamento único à consciência universal. São Paulo: Record, 2000.

SIMPSON, Paul. Language, Ideology and Point of view. New York: Routledge, 1993.

SOUZA, Martha Julia Martins de. Chico Mendes's Case: an investigation into online newspapers. 2012. Dissertação (Mestrado em Estudos Linguísticos e Literários do Inglês) Programa de Pós-Graduação em Inglês, Universidade Federal de Santa Catarina, Florianópolis, 2012. p. 130.

VENTURA, Zuenir. Chico Mendes: crime e castigo. São Paulo: Companhia das Letras, 2003.

\section{Primary Sources}

BBC NEWS. Brazil remembers slain activist. BBC News, London, 2008. Available at: http://news.bbc.co.uk/2/hi/7795194.stm. Accessed in: May 08, 2021.

BBC NEWS. The life and legacy of Chico Mendes. BBC News, London, 2008. Available at: http://news.bbc.co.uk/2/hi/7795175.stm. Accessed in: May 08, 2021.

FOLHA DE S. PAULO. Chico Mendes é "Che Guevara da era ambiental", diz "Guardian". Folha de S. Paulo, São Paulo, 2008. Available at: https://www1.folha.uol.com.br/bbc/2008/12/482239-chico-mendes-e-che-guevara-da-eraambiental-diz-guardian.shtml. Accessed in: May 08, 2021.

FOLHA DE S. PAULO. Comissão anistia Chico Mendes com R \$ 337 mil; viúva receberá R\$ 3.000 mensais. Folha de S. Paulo, São Paulo, 2008. Available at:

https://m.folha.uol.com.br/poder/2008/12/477685-comissao-anistia-chico-mendes-com-r-337mil-viuva-recebera-r-3000-mensais.shtml. Accessed in: May 08, 2021.

SIMONS, Marlise. Brazilian who fought to protect the Amazon is killed. The New York Times, New York City, 1988. Available at: https://www.nytimes.com/1988/12/24/world/brazilian-who-fought-to-protect-amazon-iskilled.html . Accessed in: May 08, 2021. 
THE NEW YORK TIMES. Brazil burns the future. The New York Times, New York City, 1988. Available at: https://www.nytimes.com/1988/12/28/opinion/brazil-burns-the-

future.html. Accessed in: May 08, 2021.

Artigo submetido em: 18 abr. 2021

Aceito para publicação em: 08 maio 2021

DOI: http://dx.doi.org/ 10.22456/2238-8915.113135

Organon, Porto Alegre, v. 36, n. 71, p. 415-430, jan./jun. 2021.

DOI: $10.22456 / 2238-8915.113135$ 